\title{
Stigmella pruinosa (Lepidoptera: Nepticulidae), a species feeding on Guazuma and exhibiting extraordinary sexual dimorphism, now known to be occurring from Mexico to Colombia
}

Jonas R. Stonis ${ }^{1,2^{*}}$,

Andrius Remeikis ${ }^{2}$,

Sergio A. Vargas ${ }^{3}$

${ }^{1}$ Vytautas Magnus University,

K. Donelaičio St. 58,

Kaunas 44248, Lithuania

${ }^{2}$ Nature Research Centre

and Baltic-American

Biotaxonomy Institute,

Akademijos St. 2,

Vilnius 08412, Lithuania

${ }^{3}$ Jardín Botánico

de Bogotá José

Celestino Mutis,

Av. Calle 63 No. 68-95,

Bogotá, Colombia
We document a sample of Stigmella pruinosa Puplesis \& Robinson, 2000, collected for the first time in Colombia in 2019. We also provide updated data on the biology and significantly wider distribution of the species, and describe outstanding sexual dimorphism of S. pruinosa. The males possess seven different androconia on both sides of the forewing, upper side of hindwing, and the abdomen. Some of these androconia were previously either unknown or poorly illustrated.

Keywords: androconial scales, sexual dimorphism, leaf mines, Nepticulidae, pygmy moths, Stigmella pruinosa

\section{INTRODUCTION}

Nepticulidae (or pygmy moths) is a very distinctive, easily recognizable family of primitive, monotrysian Lepidoptera. The family comprises the smallest lepidopterans on the planet, which occur in almost all terrestrial biomes from tundra to sandy deserts and rainforest. Larvae of pygmy moths are

* Corresponding author. Email: stonis.biotaxonomy@gmail.com leaf miners during all larval instars, with pupation in a cocoon usually spun outside of the mine. Many of Nepticulidae are pests of cultivated or otherwise economically important plants.

The Colombian fauna of Nepticulidae is still in the initial stage of study. In February-early March 2019, we conducted fieldwork in southwestern Colombia, Departamento de Valle del Cauca, Municipio de Dagua: El Naranjo (550 m), and Lobo Guerrero $(850 \mathrm{~m})$. The field studies yielded a discovery of ten taxa, all new to the fauna of 


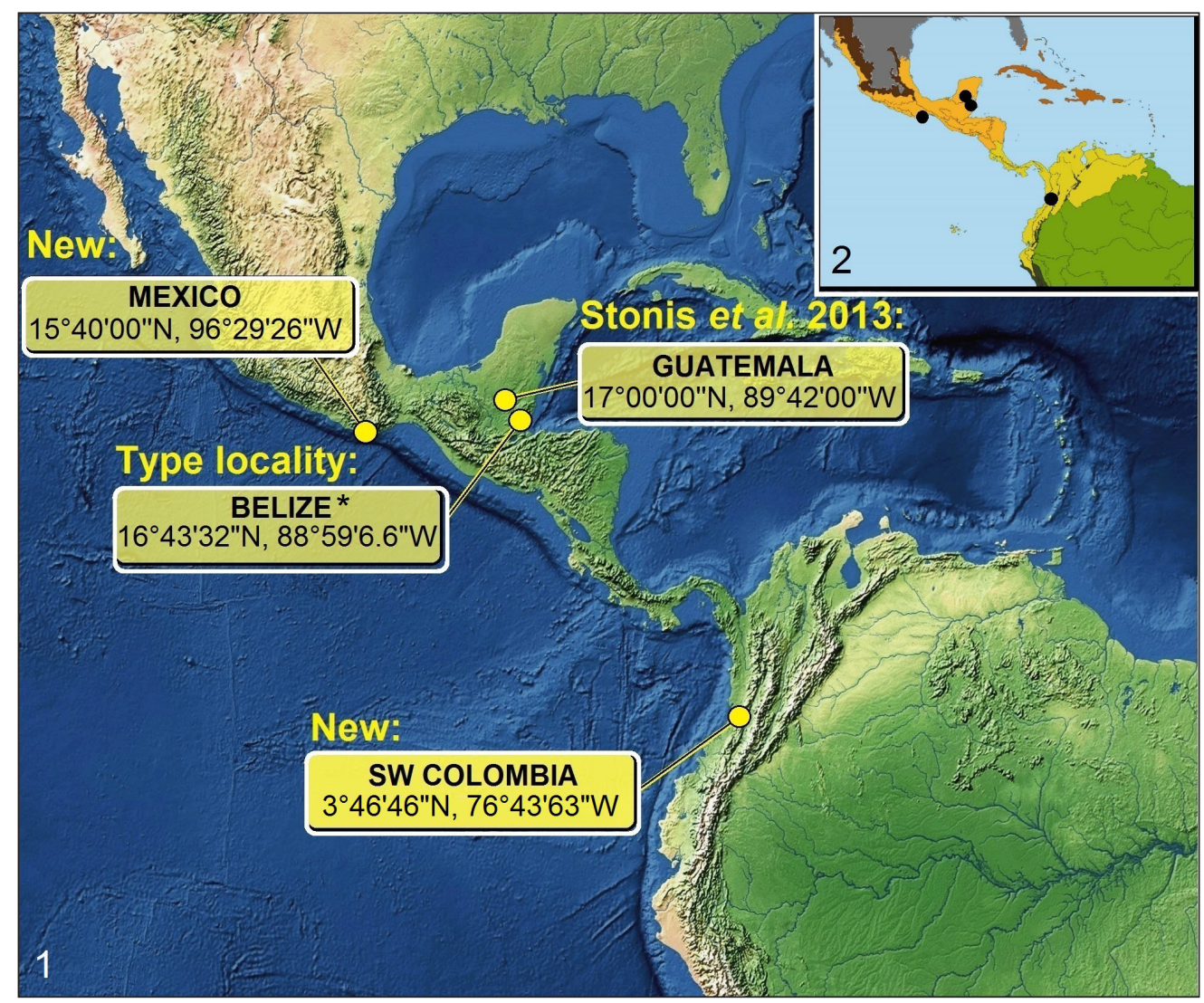

Figs. 1, 2. Updated, significantly broader distribution of Stigmella pruinosa Puplesis \& Robinson, which now is also known in Mexico and Colombia. 1 - localities where the occurrence of the species has been registered (the map base, courtesy of Tom Patterson, USA); 2 - same localities on a map of biogeographical regionalization provided in Stonis et al., 2017)

Colombia. In our collected material, the most prolific was Stigmella pruinosa, a species previously known only from Central America (Puplesis, Robinson, 2000; Stonis et al., 2013). Larvae of this species feed on guácimo (Guazuma ulmifolia, Malvaceae). During the fieldwork, we observed leaf mines of $S$. pruinosa in mass quantities; however, we had difficulty in rearing adults from mining larvae (except a single female). Hundreds of larvae died or their spun cocoons did not produce adults for unknown reasons. However, we managed to collect adults at mercury-vapour light, and they were the most prolific in comparison with all other Nepticulidae species collected by light trap during our fieldwork. When examining a large series of fresh material in a laboratory, we noticed that, externally, males of S. pruinosa were more ornate and possessed more diverse androconia than it had been known and described earlier. This fact motivated us to prepare the current paper, report on a new distribution of the species, and document the case of extraordinary sexual dimorphism in Nepticulidae. We also hope that this small paper could stimulate further studies in Colombia, a megadiverse country yet so little studied as regards nepticuloids and some other tiny leaf miners.

\section{MATERIALS AND METHODS}

The paper deals mostly with the material collected in Colombia (Valle del Cauca) by Jonas R. Stonis and Sergio A. Vargas, assisted by Franklin J. Galindo (Collecting Permit No. 2019007511-1-000 by Autoridad Nacional de Licencias Ambientales (National Authority of Environmental Licences, Bogotá, Colombia) 
and deposited at the collection of Laboratorio de Entomología, UNESIS, Departamento de Biología, Pontificia Universidad Javeriana, Bogotá, Colombia (MPUJ).

Additional "old" material on Stigmella pruinosa used for comparison came from three sources: Natural History Museum, London, UK (NHMUK), Biosystematics Research Group, Vilnius, Lithuania (BRG, formerly LEU), and Zoological Museum, University of Copenhagen, Denmark (ZMUC).

Collecting methods and protocols for species identification and description are outlined in Puplesis, Diškus (2003) and Stonis et al., 2018. After maceration of the abdomen in $10 \%$ $\mathrm{KOH}$ and subsequent cleaning, male genital capsules were removed from the abdomen and mounted ventral side uppermost. Abdominal pelts and female genitalia were stained with Chlorazol Black (Direct Black 38/Azo Black) (for a detailed description of the method, see Stonis et al., 2014).

Permanent preparations on microscope slides were photographed and studied using a Leica DM2500 microscope and a Leica DFC420 digital camera. Adults were photographed using a Leica S6D stereoscopic microscope with a Leica DFC290 digital camera attached, except for Figs. 15, 16, 33, and 34, which were photographed using a Russian Lomo MBS10 stereoscopic microscope and a temporarily attached cellular telephone Samsung Galaxy S7 with a camera.

The descriptive terminology of morphological structures follows Puplesis \& Diškus (2003), except for the term "aedeagus", which is referred here as "phallus", and the term "cilia", which is referred here as "fringe".

\section{DOCUMENTATION OF STIGMELLA PRUINOSA ON THE BASIS OF A SAMPLE COLLECTED IN COLOMBIA}

Stigmella pruinosa Puplesis \& Robinson, 2000: 38,39

Material examined: COLOMBIA: $20 \curvearrowright$, 3 , Valle del Cauca, Dagua, El Naranjo, $550 \mathrm{~m}$, at light, $3^{\circ} 46^{\prime} 46^{\prime \prime} \mathrm{N}, 76^{\circ} 43^{\prime} 63^{\prime \prime} \mathrm{W}, 21-23.1 i .2019$,
J. R. Stonis \& S. A. Vargas, genitalia slide nos. RA1020 ${ }^{\wedge}, \mathrm{RA} 1021 \%$, RA1022ㅇ (MPUJ); 1 ㅇ, Lobo Guerrero, 850 m, 345'58”N, 76² $40^{\prime} 43^{\prime \prime} \mathrm{W}$, larvae on Guazuma ulmifolia Lam., fieldcard no. SV001, 11.ii-3.iii.2019, J. R. Stonis and S. A. Vargas, genitalia slide no. RA1019 (MPUJ); also numerous leaf mines (empty or with larvae) from Lobo Guerrero and El Naranjo (MPUJ, BRG).

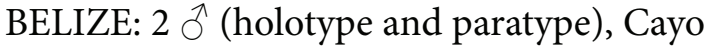
District, Chiquibul Forest Reserve, Las Cuevas, secondary forest close to Las Cuevas Research Station, at light, $16^{\circ} 43^{\prime} 32^{\prime \prime} \mathrm{N}, 88^{\circ} 59^{\prime} 6.6^{\prime \prime} \mathrm{W}$, 3-16.iv.1998 (R. Puplesis \& S. Hill), genitalia slide no. 29124 (NHMUK); 9 Ô, 7 O, San Ignacio, disturbed secondary lowland moist tropical forest at town edge, at light, 17-18. iv.1989 (R. Puplesis \& S. Hill), genitalia slide

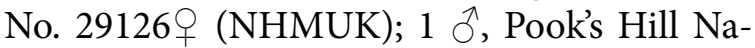
ture Reserve (S of Teakettle Village), secondary lowland moist tropical forest close to main camp, at light, 28-29.iv.1998 (R. Puplesis \& S. Hill), genitalia slide no. AD0308 $\widehat{~(B R G ; ~ t o ~}$ be deposited at NHMUK).

GUATEMALA: $2 \widehat{\diamond}$ (only genitalia from developed pupae, no pinned adults/moths available), 1 ㅇ, Petén Region, El Caoba, $17^{\circ} 00^{\prime} 00^{\prime} \mathrm{N}$, $89^{\circ} 42^{\prime} 00^{\prime \prime} \mathrm{W}$, mining larvae on Ulmaceae (now identified as Guazuma ulmifolia), elevation ca. $300 \mathrm{~m}$, 14.ii.2012, field card no. 5121, LTGT Scientific Expedition, genitalia slides nos. RA477, RA493, RA494) (ZMUC).

MEXICO: 1 +, Oaxaca Region, Pacific Coast, Puerto Angel, $15^{\circ} 40^{\prime} 00^{\prime \prime} \mathrm{N}, 9^{\circ} 29^{\prime} 26^{\prime \prime} \mathrm{W}$, $20 \mathrm{~m}$, secondary forest, mining larvae on "Planera aquatica" (a misidentification, now Guazuma ulmifolia), 30. xi. 2008 (J. R. Stonis \& S. R. Hill), genitalia slide no. AG018 (BRG); also numerous leaf mines (empty or with larvae) from Puerto Angel and Zipolite (fieldwork card no. 4959, BRG).

Diagnosis. Stigmella pruinosa can be easily distinguished from all other Neotropical Stigmella by the external characters of the male, particularly the prominent androconial scaling (see Figs. 19-35), also by the male and female genitalia. In the male genitalia, $S$. pruinosa differs from all other species in 

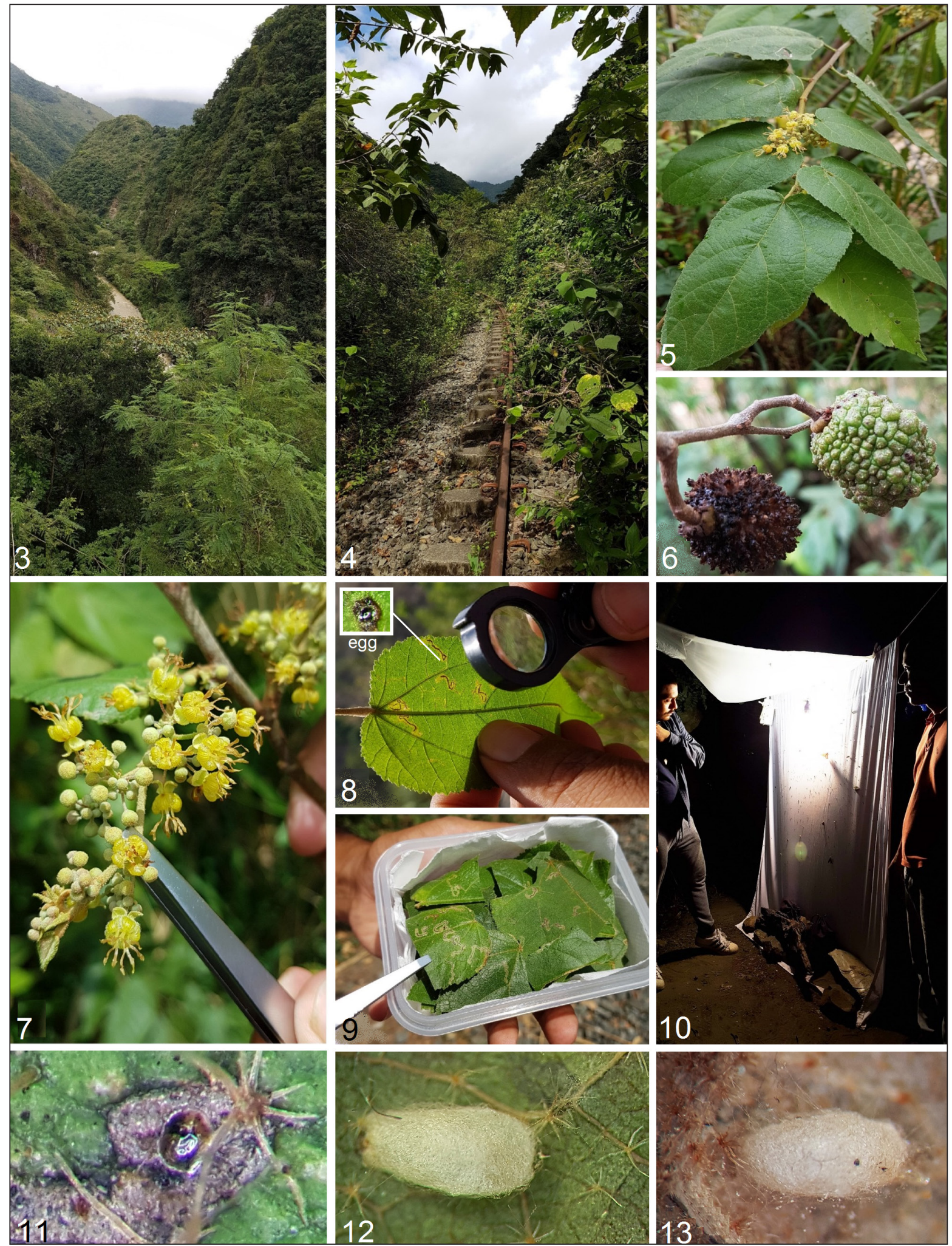

Figs. 3-13. Bionomics and collecting of Stigmella pruinosa Puplesis \& Robinson, southwestern Colombia, Departamento de Valle del Cauca, Municipio de Dagua. 3, 4 - habitat, El Naranjo, ca. 550 m; 5-7 - host plant, guácimo (Guazuma ulmifolia Lam., Malvaceae); 8, 9 - collecting of leaf mines with feeding larvae; 10 - collecting by attracting adults to mercury-vapour light from a lamp suspended in front of a white screen (light-collecting) (left to right, Sergio A. Vargas, Franklin J. Galindo); 11 - an egg on the host-plant leaf; 12, 13 - cocoons 


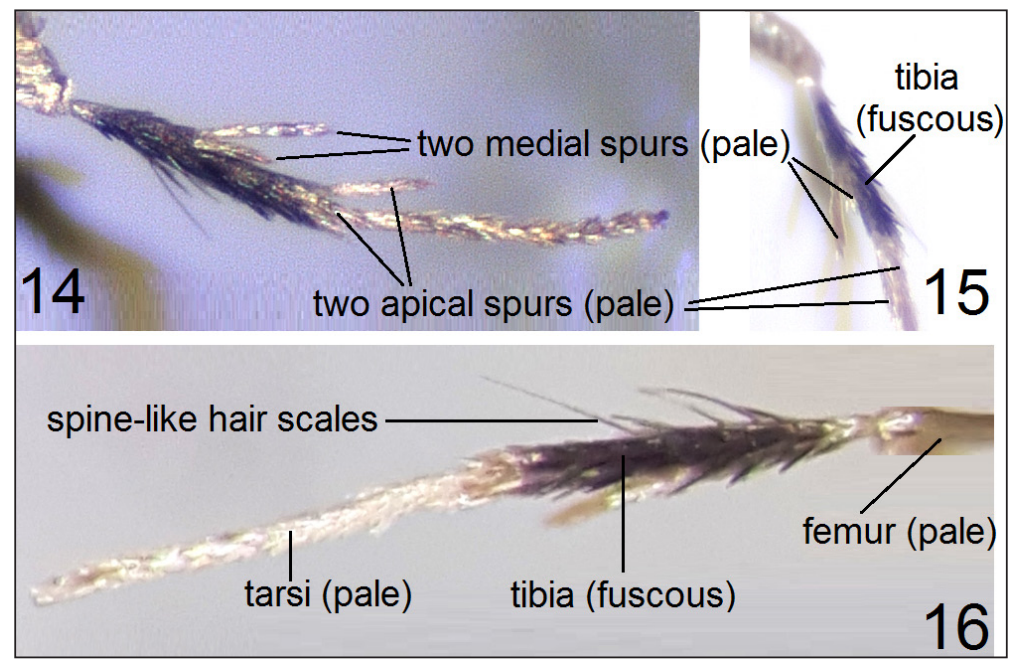

Figs. 14-16. Hindleg of Stigmella pruinosa Puplesis \& Robinson, different males, Colombia, Valle del Cauca, El Naranjo (MPUJ). Note: same fuscous tibia is characteristic of the specimens from other localities (and countries), also of females, including the paratypes from Belize

the specific band of wide triangular cornuti (Figs. 41, 42), greatly chitinized (and therefore dark), bilobed uncus, $\mathrm{M}$-shaped gnathos, and the pointed, inwardly bent apical process of valva (Fig. 39). In the female genitalia, the species differs from all other known Neotropical Stigmella in the combination of a pair of chitinized ovipositor pads (Figs. 43), unique round fold at the proximal end of the corpus bursae, and by an absence of pectinations or signum. The host plant (Guazuma ulmifolia) also makes this species distinctive.

Sexual dimorphism (Figs. 17-35). In contrast to uniformly scaled females, males of Stigmella pruinosa possess seven different androconia.

Androconia 1 ( $w \boldsymbol{s} f)$, white slender scales on the forewing: usually silvery glossy, always prominent, cover most of the distal half forewing (Figs. 19-22) or more (Fig. 23), and also occurs along the dorsal margin of the forewing base (Fig. 23), also a little on distal margin of the thorax.

Androconia 2 (brh), black rounded scales on the hindwing: particularly distinctive (Figs. 25-28), small (Figs. 29, 30), deep black, glossy, with very little purple iridescence, cover half of the hindwing on upper side.

Androconia 3 (wsh), white slender scales on the hindwing: similar to those on forewing upper side, strongly contrasting in size and colour with black rounded scales (Figs. 20, 24-28).
Androconia 4 (wos), white overlapping slender scales on the hindwing: sometime difficult to notice (Figs. 27, 28, 31) but easily visible from beneath (Figs. 32, 35).

Androconia 5 (bos), black overlapping slender scales on the hindwing: usually difficult to notice (Figs. 27, 28, 31, 33) but still visible from beneath among longer white androconia (Figs. 32, 35).

Androconia $6(p b f)$, patches of black scales on the forewing underside: usually there are two distinct, elongated patches of small black scales (Figs. 31, 32); however, sometimes one of the patches is developed weaker or both patches can be partially rubbed in dry specimens of the collection. These androconia were previously unknown for the species, also neither noticed nor described either in the primary description (Puplesis, Robinson, 2000), or in Stonis et al., 2013.

Androconia 7 (psa), pale scales on upper side of the abdomen: cover half of abdomen (or more) proximally (Figs. 33, 34), wide, brownish cream, sometime less distinct or partially rubbed in collection specimens; these androconia were previously unknown for the species, neither noticed nor described either in the primary description (Puplesis, Robinson, 2000) or in Stonis et al., 2013.

Male (Figs. 14-16, 19-35). Forewing length: 1.5-1.7 mm. Wingspan: 3.4-3.9 mm. Head: palpi cream, glossy; frontal tuft pale, yellowish 


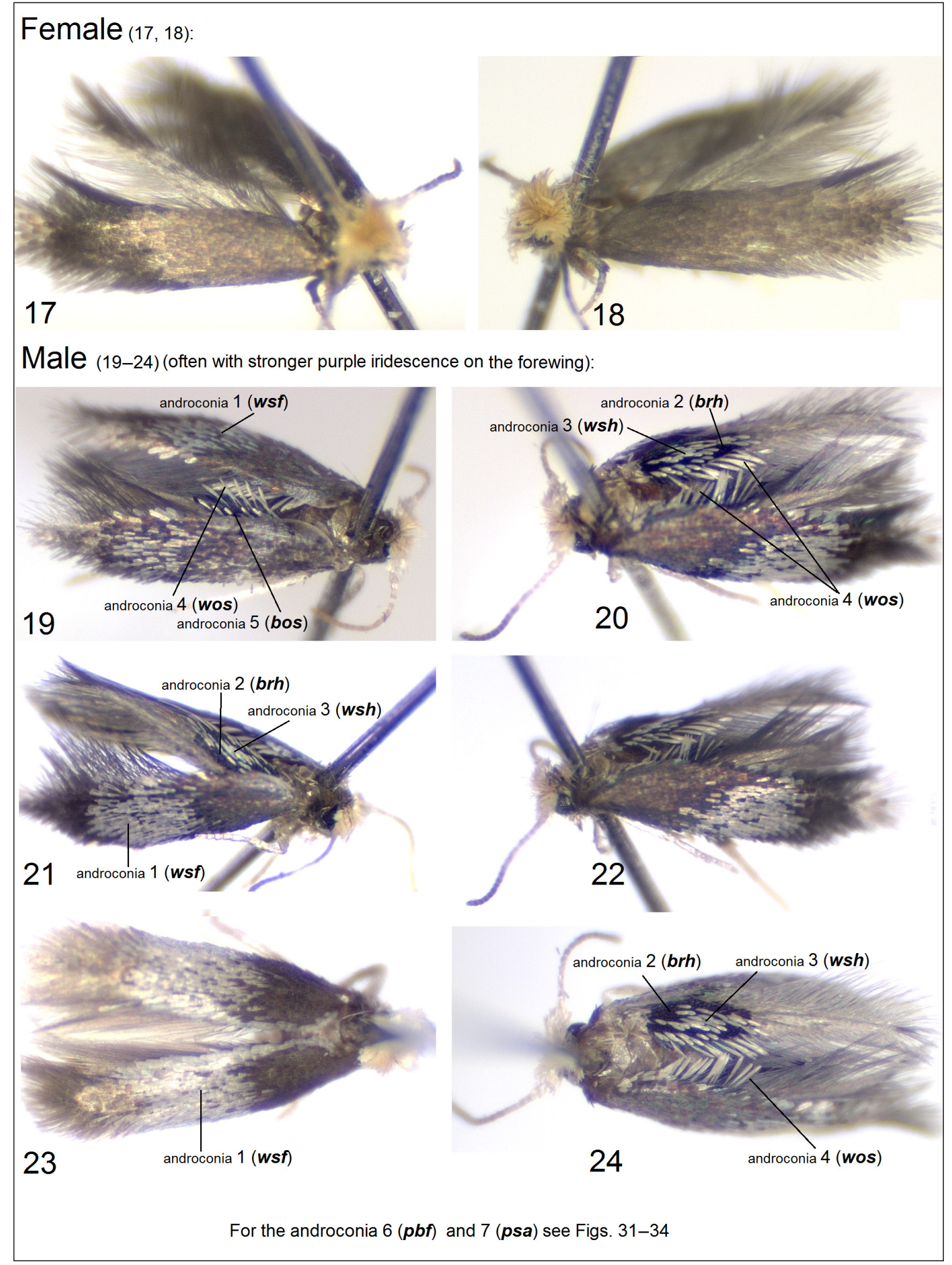

Figs. 17-24. Adults of Stigmella pruinosa Puplesis \& Robinson. 17, 18 - females, paratypes, Belize (NHMUK); 19-24 - males, Colombia, Valle del Cauca, El Naranjo (MPUJ): androconia 1 (wsf), white slender scales on the forewing; androconia 2 (brh), black rounded scales on the hindwing; androconia 3 (wsh), white slender scales on the hindwing; androconia 4 (wos), white overlapping slender scales on the hindwing; androconia 5 (bos), black overlapping slender scales on hindwing 


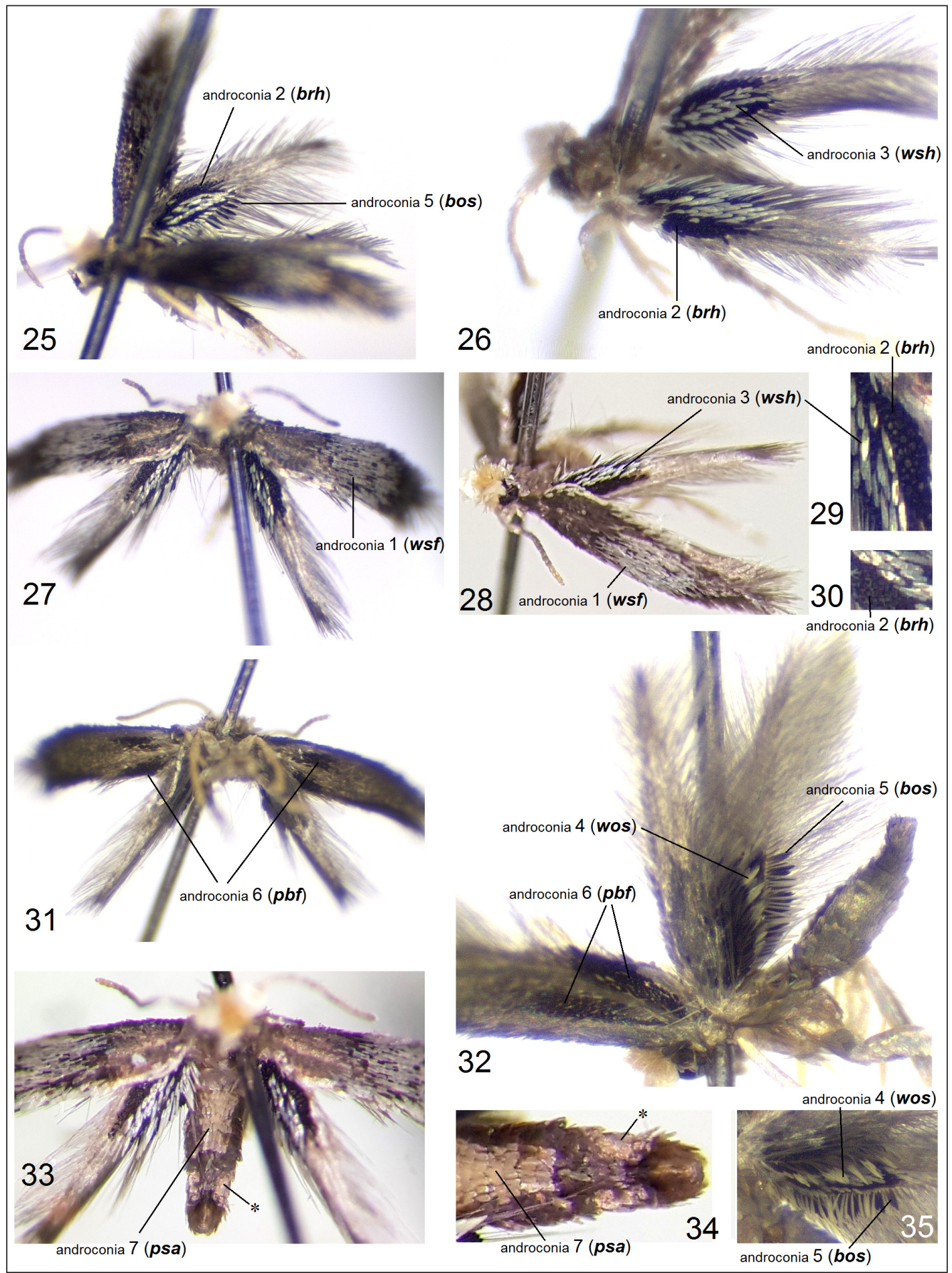

Figs. 25-35. Male adults of Stigmella pruinosa Puplesis \& Robinson. 25-28 - general view; 29, 30 - androconia on the upper side of hindwing; 31, 32, 35 - venter of male adult; 33, 34 - androconia on the upper side of abdomen (MPUJ): androconia 1 ( $w \boldsymbol{s} f)$, white slender scales on the forewing; androconia 2 (brh), black rounded scales on the hindwing; androconia 3 ( $\boldsymbol{w} \boldsymbol{s} \boldsymbol{h}$ ), white slender scales on the hindwing; androconia 4 (wos), white overlapping slender scales on the hindwing; androconia 5 (bos), black overlapping slender scales on the hindwing; androconia 6 (pbf), patches of black scales on the forewing underside; androconia 7 (psa), pale scales on the upper side of abdomen. $\left(^{*}-\right.$ incidental, technical gloss because the photography) 
ochre to pale orange; collar cream, glossy; scape golden glossy; antenna distinctly shorter than half of the forewing; flagellum comprised of 19-20 segments, grey, with some golden gloss and green iridescence. Thorax and tegulae grey to dark grey, golden glossy, with distinct (sometimes strong) purple iridescence. Forewing dark grey with slender, silvery glossy androconial scales; fringe dark grey; underside of forewing grey, with little purple iridescence and two elongated spots of black androconia. Hindwing brownish-grey to grey, with a very distinct androconial patch on the basal half comprised of deep black, rounded scales and silvery white, slender ones; additionally, black and white androconial scales overlap fringe; fringe grey to pale grey; underside of hindwing grey, glossy, without androconia. Legs very glossy, cream to brownish cream, except foreleg and tibia of hind leg, including its bristles: they are covered with dark grey or black scales (Figs. 14-16). Abdomen blackish-grey to grey, with wide brownish cream androconial scales in the proximal half on the upper side, metallic grey, with little purple iridescence on underside; anal tufts short, indistinct; genital segments small, metallic grey, sometimes pale brown.

Female (Figs. 17, 18). Forewing length: 1.6$1.7 \mathrm{~mm}$. Wingspan: $3.5-3.8 \mathrm{~mm}$ antenna shorter than $1 / 3$ of the forewing length; flagellum with ca. 16 segments, pale brown to brown, except three proximal segments which are cream. Thorax, tegulae, and forewing concolorous, grey-brown to bronzey grey, glossy, with little purple iridescence; forewing without white (androconial) scales. Hindwing pale grey-brown to brown-grey, without patches on upper side and underside; fringe pale greybrown. Scaling of legs as in male, hind leg and its bristles dark grey to black. Abdomen dark grey to grey, glossy, sometime with little purple iridescence, without brownish cream scales on upper side, cream on underside, dark grey laterally; sometimes entirely dark grey on underside and laterally; anal tufts surrounding a short pointed ovipositor grey.

Male genitalia (Figs. 36-42). Capsule about 205-210 $\mu \mathrm{m}$ long, $150 \mu \mathrm{m}$ wide. Uncus with two wide, strongly chitinized (therefore black) lateral lobes and very weak caudal emargination between the lobes. Gnathos very strongly chitinized, with two posterior and two anterior processes on a short transverse bar (central plate); anterior processes one-third longer than posterior ones and almost twice as widely spaced; lateral arms short. Valva about $115 \mu \mathrm{m}$ long, 40$45 \mu \mathrm{m}$ wide, gradually narrowed towards apex, which is heavily chitinized, pointed and bent inwardly. Transtilla rounded laterally, without sublatera1 processes. Vinculum relatively large, ventral plate with a wide emargination anteriorly and with triangular, distally rounded lateral lobes. Phallus (Fig. 42) very large, about 275-280 $\mu \mathrm{m}$ long, 55-85 $\mu \mathrm{m}$ wide, without carinae; vesica with a band of wide, spine-like cornuti and many loose, small cornuti close to vesica; vesica relatively weakly sclerotized, with tiny spines (Fig. 41).

Female genitalia (Figs. 43-46). Total length $750-920 \mu \mathrm{m}$. Abdominal apex with a pair of specific, chitinized pads (Figs. 43, 44). Apophyses posteriores and apophyses anteriores almost same length (up to $150-160 \mu \mathrm{m}$ ), but apophyses posteriores very slender. Vestibulum very narrow. Caudal part of corpus bursae very wide, with a specific, rounded fold (Figs. 43, 44); remaining larger part of corpus bursae without pectinations or signum. Accessory sac weakly separated from bursa or totally absent; ductus spermathecae with about 2.5-3 coils (Fig. 46).

Bionomics (Figs. 3-13, 47-51). Mines in the leaves of the guácimo tree (Guazuma ulmifolia Lam., Malvaceae) (Figs. 5-7). Egg (Fig. 11) oval or round, very glossy, usually with some remnants of black frass, therefore brown-black to black; laid away from main veins, on upper side of the leaf, mainly in basal half of the leafblade (Fig. 48). Larva yellowish green, with brownish green intestine, and yellowish brown head (Fig. 51). Mining occurs in January and early February, and then, other generation, starts in late February-early March, and possibly later in a year but that has not confirmed by our research. Mining very abundant in Lobo Guerrero (ca. $850 \mathrm{~m}$ ) in a relatively dry habitat along the abandoned railway or settlements but 


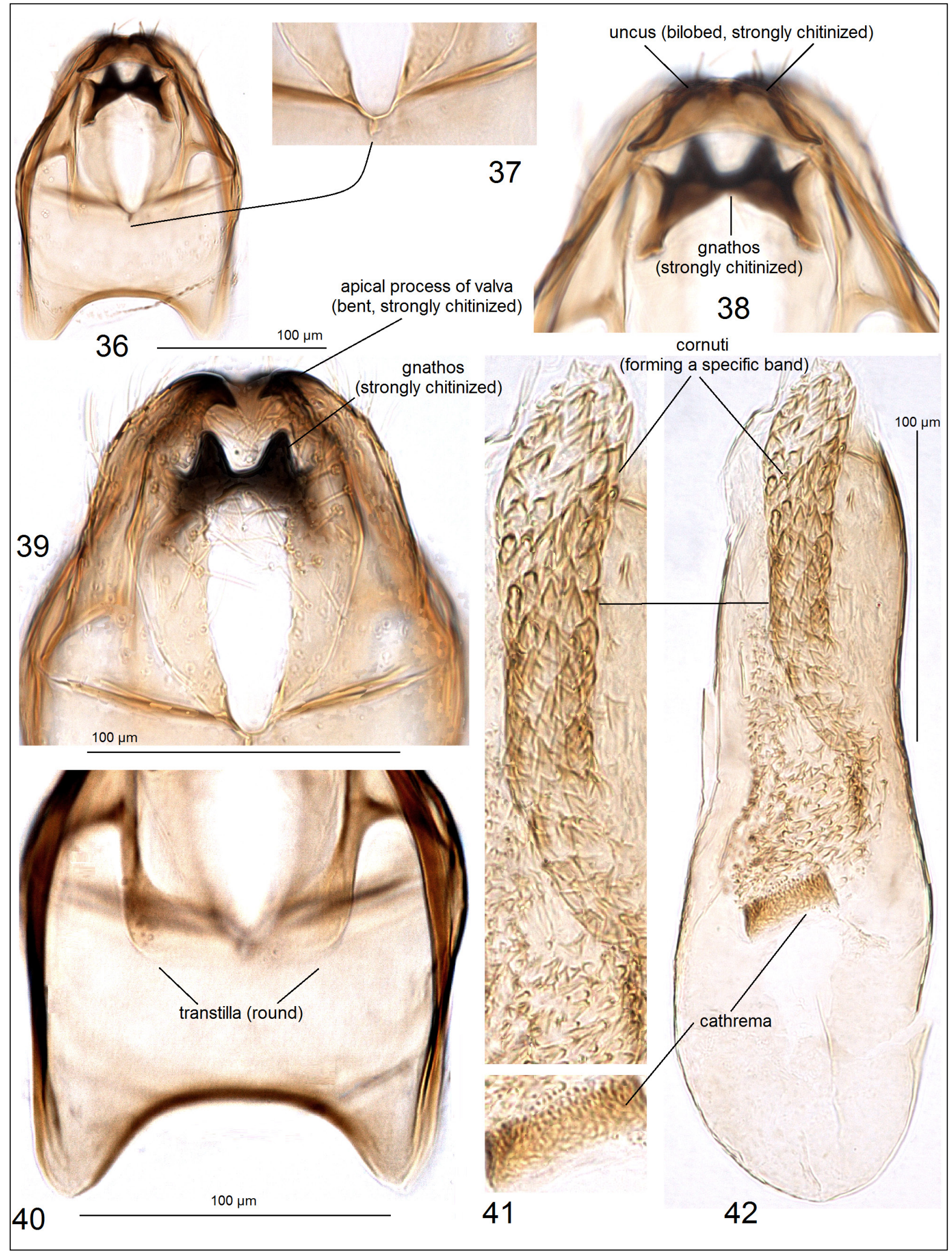

Figs. 36-42. Documentation of male genitalia of Stigmella pruinosa Puplesis \& Robinson, collected in Colombia, Valle del Cauca, El Naranjo, genitalia slide no. RA1020 (MPUJ). 36-40 - details of genital capsule, with phallus removed; 41 - cornuti and cathrema (below); 42 - phallus 


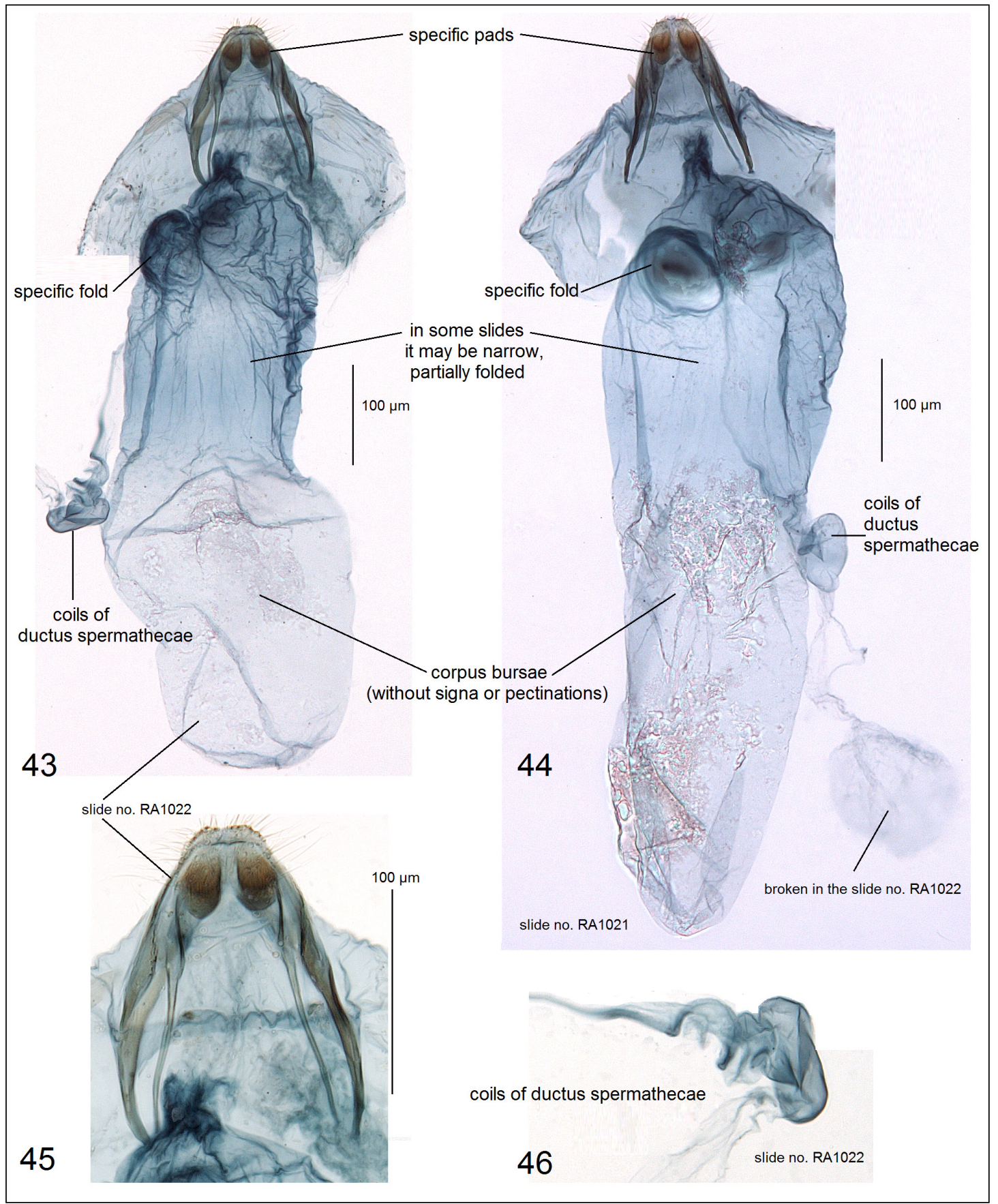

Figs. 43-46. Documentation of female genitalia of Stigmella pruinosa Puplesis \& Robinson, collected in Colombia, Valle del Cauca, El Naranjo. 43 - a general view, genitalia slide no. RA1022 (MPUJ); 44 - same, genitalia slide no. RA1021 (MPUJ); 45 - ovipositor and apophyses, genitalia slide no. RA1022; 46 - same, distal part of ductus spermathecae

becomes less abundant towards more tropical and moist areas at lower elevations. Leaf mine relatively short, sinuous gallery with a line of black to brown-black frass (Figs. 47-51); in older leaf mines, frass may turn brown (Fig. 47). Lar- val exit slit on the upper side of the leaf. Cocoon greyish white, narrowed basally, often weakly spinned, flimsy, about $1.4 \mathrm{~mm}$ long, $0.7 \mathrm{~mm}$ wide (Figs. 12, 13). Adults attracted by light, collected in abundance at light trap in February (Fig. 10). 

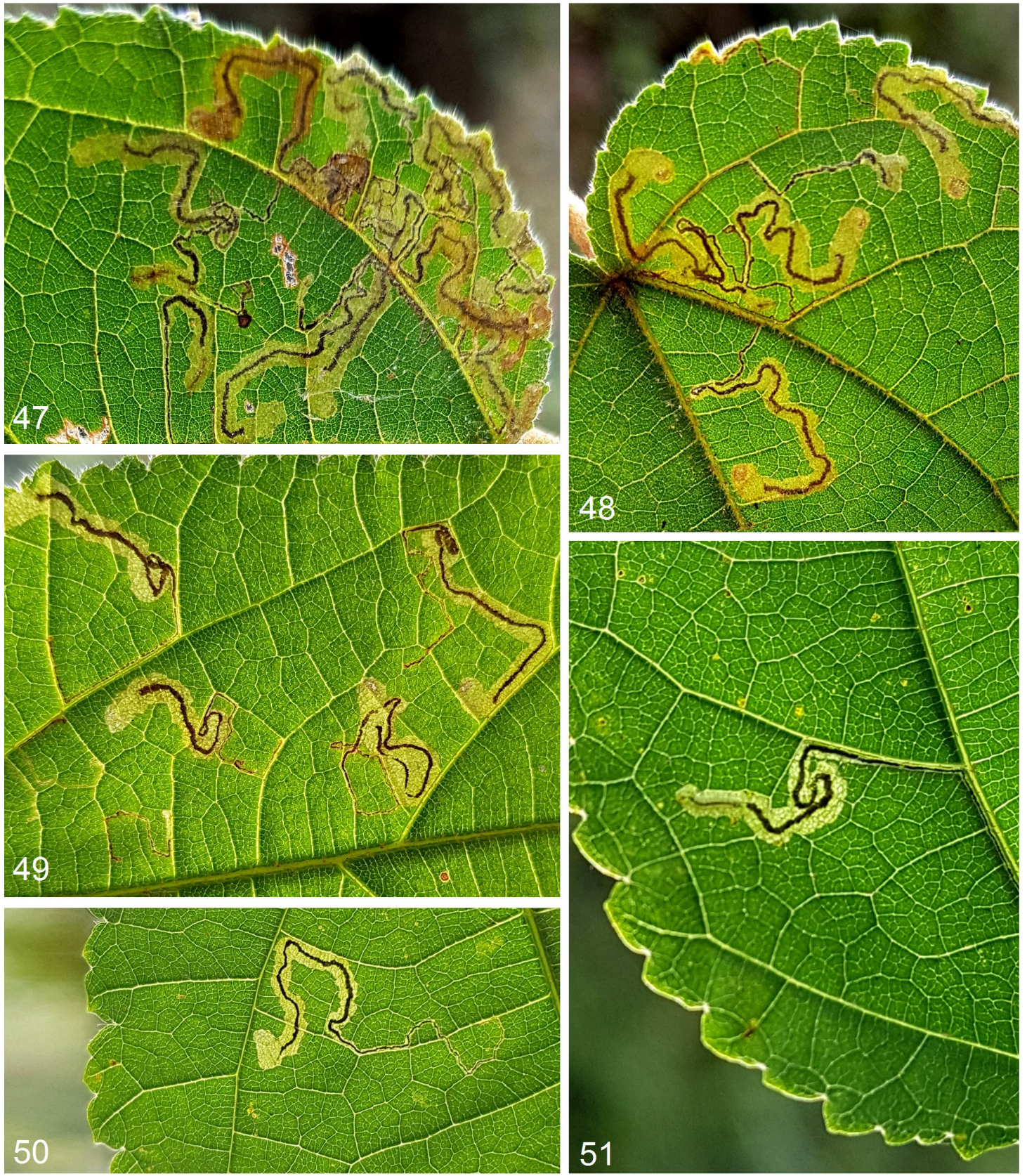

Figs. 47-51. Leaf mines of Stigmella pruinosa Puplesis \& Robinson on Guazuma ulmifolia Lam., Malvaceae, Colombia, Valle del Cauca, Lobo Guerrero, $850 \mathrm{~m}, 3^{\circ} 45^{\prime} 58^{\prime \prime} \mathrm{N}, 76^{\circ} 40^{\prime} 43^{\prime \prime} \mathrm{W}$, fieldcard no. SV001, 11.ii-3.iii.2019, J. R. Stonis and S. A. Vargas

Distribution (Figs. 1, 2). The species is known as widespread and common in Belize (the Maya Mountains, Chiquibul Forest Reserve, in premontane moist tropical forest, and San Ignacio, in disturbed secondary lowland moist tropical forest, and Pook's Hill Nature Reserve, secondary lowland moist tropical forest) (Puplesis, Robinson, 2000), also common in Guatemala (Petén
Region, in lowland secondary evergreen broadleaf tropical forest near Lago Petén Itzá) (Stonis et al., 2013). Now the species has been recorded from southern Mexico (Fig. 1) (also see Discussion) and southwestern Colombia (Figs. 1, 3, 4); both in Mexican locality and our collecting sites in Colombia the species was found as very common, with characteristic very prolific mining. 


\section{DISCUSSION}

Sexual dimorphism. In Nepticulidae, male and female adults may often slightly differ in size, the length of antenna (females usually have a slightly shorter flagellum), the intensity of coloration of the thorax, forewing, or (and) frontal tuft (females often darker or paler, more coarsely scaled, and with a wider fascia than males), the intensity of purple iridescence (if present), and some other features. Most of them are rather indistinct and overlapping when large series of males and females are examined, and, therefore, seldom applicable for the species diagnostics. Males of Nepticulidae also often possess distinctive but short anal tufts, which are absent or different in females. However, a "real" case of sexual dimorphism was observed in some peculiar species where males had broadened hindwing like in the Mediterranean Acalyptris platani (Müller-Rutz), or males and females possessed scaling of different colour like in the Neotropical S. andina (Meyrick), S. calceolariae Diškus \& Stonis, and S. lachemillae Diškus \& Stonis, or where males and females were significantly different size-wise (notably, females of the Neotropical S. lachemillae Diškus \& Stonis and S. acalyphae Diškus \& Stonis were found to be smaller than representatives of the opposite sex, not following the general nepticulid "trend", where females tend to be slightly larger).

The other, very distinct case of sexual dimorphism is when males develop androconial structures, which have been observed in many Nepticulidae genera like Glaucolepis, Ectoedemia, including the European E. andalusiae van Nieukerken, E. hendrikseni A. Laštuvka, Z. Laštuva \& van Nieukerken, E. phaeolepis van Nieukerken, A. Laštuvka \& Z. Laštuvka, E. heckfordi van Nieukerken, A. Laštuvka \& Z. Laštuvka (van Nieukerken et al., 2010), or East Asiatic E. ortiva Rocienè \& Stonis, E. paraortiva Rocienè \& Stonis, and some other species. Androconial scales are also common in Acalyptris: e.g., they developed in the European A. minimella (Rebel), A. loranthella (Klimesh), Asiatic A. vannieukerkeni $\mathrm{Pu}-$ plesis, A. egidijui Puplesis, A. nigripexus Puplesis \& Diškus, the Neotropical A. trifidus Puplesis \&
Robinson, $A$. argentosa (Puplesis \& Robinson), A. onorei Puplesis \& Diškus, $A$. peteni Diškus \& Stonis, A. dominicanus Remeikis \& Stonis, $A$. nigrisignum Remeikis \& Stonis, and some other Acalyptris. Male androconia were also found in some Stigmella, notably in the Neotropical S. barbata Puplesis \& Robinson, S. maya Remeikis \& Stonis, the Palearctic S. longicornuta Puplesis \& Diškus, S. maculifera Puplesis \& Diškus, S. skulei Puplesis \& Diškus, S. lemniscella (Zeller), S. pyri (Glitz), East Palearctic S. micromelis Puplesis, etc. Within Stigmella, male androconia are particularly often in species from the S. ruficapitella group, including the European S. atricapitella (Haworth), S. ruficapitella (Haworth); S. suberivora (Stainton), S. ilicifoliella (Mendes), S. fasciata van Nieukerken \& Johansson, S. cocciferae van Nieukerken \& Johansson, S. kasyi van Nieukerken \& Johansson, S. karsholti van Nieukerken \& Johansson (van Nieukerken, Johansson, 2003), and others.

Androconial scales usually develop on forewing underside, hindwing upper side, or are overlapping over the fringe, and sometimes occur on abdomen (perhaps the most remarkable examples are represented in the Neotropical S. auriargentata Remeikis \& Stonis and the European S. trimaculella (Haworth) (both from different species groups), and the "tufted" species from the Asiatic Acalyptris repeteki group.

The presence or absence of androconia appear only little correlated with the phylogenetic position of the taxa, seems to be occur rather randomly in some individual species or groups of species, but always serves as a great diagnostic key for such species with androconia (for examples of the use of androconia see Johansson et al., 1990; Puplesis, 1994; van Nieukerken, Johansson, 2003; Puplesis \& Diškus, 2003; van Nieukerken et al., 2010; Stonis, Rocienè, 2014; Stonis, Remeikis, 2015).

The species documented in the current paper, S. pruinosa, represents an extraordinary case of sexual dimorphism, not previously known on such a scale among the world's Nepticulidae. Among Nepticulidae, males usually possess one or, occasionally, two sets of androconia (if any), while $S$. pruinosa has seven different androconia; 
it makes the males of the species very ornate and the species exclusive.

Position of S. pruinosa within Stigmella. The exact position of $S$. pruinosa within Stigmella, as a separate species group designated on the basis of a single species (Remeikis, 2017), is still uncertain and, therefore, provisional. The shape of the gnathos, uncus, transtilla, and the vinculum in the male genitalia, as well as the absence of pectination or signum in the female genitalia, make $S$. pruinosa the most comparable to the representatives of the $S$. oxyacanthella species group. However, among a few other differences, S. pruinosa has ovipositor pads in the female genitalia, but does not possess an inner lobe of valva in the male genitalia and an accessory sac in the female genitalia. It should be also noted that the S. oxyacanthella group is widespread and common in the Holarctics, but previously was never reported from the Neotropics. Nevertheless, judging from an undescribed species collected in 2018 in Peru (Stonis, Diškus, unpublished), the group probably occurs in South America.

Presence of S. pruinosa in Mexico. Šimkevičiūtè et al. (2009) provided documentation of Stigmella species AG018, an unnamed species, described on a single female adult which had been reared in Mexico by R. Puplesis from leaf mines on Guazuma ulmifolia, Malvaceae, originally misidentified by botanists as Planera aquatica J. F. Gmel. (Ulmaceae). The current detailed comparison of the Mexican S. species AG018 with the specimens from Belize and, particularly, with the series from Colombia undoubtedly shows $S$. pruinosa. Previously it was stated (Stonis et al., 2013) that the frass in the leaf mine of $S$. species AG018 was aggregated in a thin line, while the frass line in S. pruinosa was usually wider. However, the Colombian sample exhibited a certain variation in the width of the frass line. It was also supposed that the female abdominal tip of $S$. species AG018 was narrowed, while $S$. pruinosa possessed a wider abdominal tip; that the proximal part of corpus bursae in S. species AG018 was heavily folded and very narrow, while $S$. pruinosa possessed not folded but very wide corpus bursae. In our study, the Colombian sample exhibits certain variation in all of these features, thus there is no argument for considering $S$. species AG018 a separate species.

On the site where $S$. species AG018 (now S. pruinosa) was collected (Puerto Angel), and also on a nearby site in Zipolite, leaf mines on Guazuma were particularly abundant. It is interesting that an internet search produces photographs of Guazuma ulmifolia taken in other localities of Mexico in which one may sometimes see incidentally captured leaf mines of $S$. pruinosa. This fact may serve as evidence that $S$. pruinosa is common and much more widespread than on the Pacific Coast in Puerto Angel and Zipolite, but could be found in such locations as Michoacán, West of Uruapan (Mexico) or even in other countries, e.g. Nicaragua.

\section{ACKNOWLEDGEMENTS}

We are very grateful to Professor Dr Igor Dimitri Forero Fuentes, a coordinator of the biological collections (Departamento de Biología, Pontificia Universidad Javeriana, Bogotá, Colombia), for facilitating a permit to collect study material in Colombia and for his previous scientific collaboration. For the collecting permit, we also thank Autoridad Nacional de Licencias Ambientales, Bogotá, Colombia. We are indebted to our field assistant Franklin Jesus Galindo Meza (Cali) for his generous help during our fieldwork in Valle del Cauca. This research was partially funded by a grant (MIP-19-249/2019) from the Research Council of Lithuania. Andrius Remeikis is also grateful to the Lithuanian Research Council for the research grant he was awarded in 2019.

Received 8 May 2019 Accepted 21 May 2019

\section{References}

1. Johansson R, Nielsen ES, Nieukerken van EJ, Gustafsson B. The Nepticulidae and Opostegidae (Lepidoptera) of North West Europe. Fauna Entomol Scand. 1990; 23(1/2): 1-739. 
2. Nieukerken van EJ, Johansson R. The Quercus feeding Stigmella species of the West Palaearctic: new species, key and distribution (Lepidoptera: Nepticulidae). Tijdschrift voor Entomologie. 2003; 146: 307-370.

3. Nieukerken van EJ, Laštuvka A, Laštuvka Z. Western Palaearctic Ectoedemia (Zimmermannia) Hering and Ectoedemia Busck s. str. (Lepidoptera, Nepticulidae): five new species and new data on distribution, hostplants and recognition. ZooKeys, 2010; 32: 1-82.

4. Remeikis A. Fauna and trophic relationships of the Middle and South American Nepticuloidea (Lepidoptera: Nepticulidae, Opostegidae). Summary of doctoral dissertation, Vilnius University and Nature Research Centre, Vilnius, 2017, 71 p.

5. Puplesis R. The Nepticulidae of Eastern Europe and Asia: western, central and eastern parts. Leiden: Backhuys Publishers; 1994. 552 p.

6. Puplesis R, Diškus A. The Nepticuloidea \& Tischerioidea (Lepidoptera) - a global review, with strategic regional revisions. Kaunas: Lutute Publishers; 2003. 512 p.

7. Puplesis R, Robinson GS. A review of the Central and South American Nepticulidae (Lepidoptera) with special reference to Belize. Bull Nat Hist Mus Entomol. 2000; 69(1): 3-114.

8. Stonis JR, Diškus A, Carvalho Filho F, Lewis OT. American Asteraceae-feeding Astrotischeria species with a highly modified, three-lobed valva in the male genitalia (Lepidoptera, Tischeriidae). Zootaxa. 2018; 4469(1): 001-069.

9. Stonis JR, Diškus A, Remeikis A, Navickaitè A. Study methods of Nepticulidae: micro-mounts of genitalia structures. In: Stonis JR, Hill SR, Diškus A, Auškalnis T, editors. Selected abstracts and papers of the First Baltic International Conference on Field Entomology and Faunistics. Vilnius: Edukologija Publishers; 2014. p. 32-5.

10. Stonis JR, Diškus A, Remeikis A, Noreika R, Schuster J. Four new leaf-mining Acalyptris species from Guatemala and Belize, with new data on bionomics of Stigmella pruinosa
(Lepidoptera: Nepticulidae). Zootaxa. 2013; 3737(2): 101-17.

11. Stonis JR, Remeikis A. The first records on the genus Acalyptris from the Caribbean (Lepidoptera: Nepticulidae). Zootaxa. 2015; 4057(1): 79-90.

12. Stonis JR, Rociene A. Additions to the Nepticulidae (Lepidoptera) of East Asia, with descriptions of three new species from Primorskiy Kray. Zootaxa. 2014; 3846(2): 204-20.

13. Šimkevičiūtè A, Stonis JR, Diškus A. Taxonomic checklist of Nepticulidae of Mexico, with the description of three new species the from Pacific Coast (Insecta, Lepidoptera). Acta Zool Lituan. 2009; 19(4): 268-77.

\section{Jonas Rimantas Stonis, Andrius Remeikis,} Sergio Andreas Vargas

\section{NAUJI DUOMENYS APIE GUAZUMA LAPUS MINUOJANČIO MAŽOJOJO GAUBTAGAL- VIO STIGMELLA PRUINOSA (LEPIDOPTERA: NEPTICULIDAE) GEOGRAFINI PAPLITIMĄ IR NEĮPRASTĄ LYTINİ DIMORFIZMĄ}

\section{Santrauka}

Guazuma ulmifolia Lam. lapus minuojantis mažasis gaubtagalvis Stigmella pruinosa Puplesis \& Robinson pasižymi išskirtiniu, iki šiol tarp Nepticulidae šeimos atstovų nežinomu lytiniu dimorfizmu. Patinams būdingi septyneri skirtingi androkonijų rinkiniai ant priekinių ir užpakalinių sparnų, taip pat pilvelio. Daugelis šių androkoninių struktūrų buvo anksčiau nežinomos arba nepakankamai dokumentuotos. Remiantis 2019 m. ekspedicinių lauko tyrimų duomenimis ir ištirta papildoma kolekcine medžiaga iš kitų šalių, pateikiamas naujas, ženkliai platesnis nei iki šiol manyta, S. pruinosa geografinis paplitimas nuo Meksikos iki Kolumbijos. Straipsnyje pirmą kartą dokumentuojamos $S$. pruinosa individų serijos, surinktos Kolumbijoje (Valle del Cauca) patinų bei patelių genitalinės struktūros, taip pat lervų gyvybinès veiklos pèdsakai - minos Guazuma ulmifolia lapuose.

Raktažodžiai: androkonijos, augalų minos, lytinis dimorfizmas, mažieji gaubtagalviai, Nepticulidae, Stigmella pruinosa 